\title{
ИННОВАЦИОННОЕ РАЗВИТИЕ АГРАРНОГО СЕКТОРА ЭКОНОМИКИ АЗЕРБАЙДЖАНА
}

\section{INNOVATIVE DEVELOPMENT OF THE AGRICULTURAL SECTOR OF THE ECONOMY OF AZERBAIJAN}

L. Khasiyeva

Summary. Currently, one of the main directions of the economic policy of the Azerbaijan government is to accelerate the transition to an innovative economy, the use of advanced technologies and the implementation of regional programs. In the article was discussed the process of changing the dynamics of the growth of the agricultural sector in the country, the positive results of flexible decisions made during the period of independence. Also, to accelerate the development of the agricultural sector, it substantiates the need to focus on examples of world practice and advanced innovations.

Keywords: innovation, agricultural sector, food security, intensive development, state program, agrarian reform.

\author{
Хасиева Лейла \\ Доцент, Бакинский Государственный Университет, \\ Баку, Азербайджан \\ khasiyeva@rambler.ru
}

Аннотация. В настоящее время одним из основных направлений экономической политики правительства Азербайджана является ускорение перехода к инновационной экономике, применение передовых технологий и реализация региональных программ. В статье обсуждается процесс изменения динамики роста аграрного сектора в стране, положительные результаты гибких решений, принятых в период независимости. Также для ускорения развития аграрного сектора здесь обосновывается необходимость сосредоточения на примерах мировой практики и передовых инновациях.

Ключевые слова: инновации, аграрный сектор, продовольственная безопасность, интенсивное развитие, государственная программа, аграрная реформа.
B результате аграрных реформ Азербайджан сегодня имеет большой потенциал для дальнейшего увеличения сельскохозяйственного производства и производительности. Для того чтобы использовать потенциальные возможности применения новых технологий в сельскохозяйственном секторе исследования В данной сфере приобретают особую актуальность. Влияние применения научно-технических идей и исследований на рост совокупного дохода в сельскохозяйственном секторе, характеризующих наиболее современное, инновационное развитие экономики, представляет собой количественную оценку с помощью современных математических моделей.

Аграрный сектор, как важный сектор экономики Азербайджана, обеспечивает около 6,2\% ВВП и около $39 \%$ занятости. Не менее двух третей потребительского фонда населения обеспечивается непосредственно им. [15]. По этой причине экономическая безопасность любой страны напрямую зависит от устойчивого развития сельского хозяйства. В то время, когда население мира быстро растет и глобальное изменение климата усиливается, необходимость государств иметь эффективный сельскохозяйственный сектор становится все более значимой. Эффективный сельскохозяйственный сектор означает, что экономика может достичь более высокого уровня сельскохозяйственного производства с меньшими ресурсами. В этом смысле в международной практике низкая или высокая производительность сельскохозяйственного производства в разных странах с одинаковыми природными и экономическими условиями показывает, насколько эффективна аграрная политика этих стран.

В результате применения научно-технических инноваций в сельскохозяйственном секторе, будет решена проблема минимизации затрат и максимизации доходов.

Для обеспечения динамичного развития аграрного сектора создана правовая социально-экономическая база. Местные фермерские хозяйства, сельскохозяйственные производственные кооперативы, семейные фермы открыли широкие возможности для полного и эффективного использования существующего природно-экономического потенциала.

Указом президента Азербайджана Ильхама Алиева, подписанным 24 ноября 2003 года «О мерах по ускорению социально-экономического развития в Азербайджанской Республике», в стране была внедрена новая модель развития аграрного сектора. Принятая 11 февраля 2004 года «Государственная программа социально-экономического развития регионов Азербайджанской 
Республики (2004-2008)», которая являлась логическим продолжением этого указа, призывала к радикальным изменениям в аграрном секторе и предпринимательстве в сельском хозяйстве. Положительный результат программы способствовал принятию аналогичной программы на 2009-2013 гг. [1, 2, 3].

Государственная программа по надежному обеспечению продовольствием населения в Азербайджанской Республике на 2008-2015 годы имело особое значение с точки зрения обеспечения продовольственной безопасности в стране. Развитие аграрного сектора, обеспечение продовольственной безопасности населения также упоминается в качестве одного из основных направлений в Концепции развития «Азербайджан 2020: взгляд в будущее».[5] Для полного продовольственного обеспечения населения страны была увеличена площадь под зерновыми культурами до 900 тыс. га и удалось повысить производство до 2.8 млн. тонн. В результате этих программ также повысилось промышленное производство мяса до 340000 тонн, молока и молочных продуктов $-2,4$ млн. тонн, мяса птиц - 80000 тонн и яиц 1,3 млрд. единиц. В стране производится 1,72 млн. тонн овощей и бахчевых культур, 1,12 млн. тонн картофеля и 800000 тонн фруктов. Так же увеличилась площадь под масличными культурами до 135000 га, а сахарной свеклы до 20000 га., производство комбикормов до 2 млн. тонн в год с общей площадью 500000 га кормовых культур. [15]

Сельское хозяйство Азербайджана обладает очень сильным потенциалом. Проведенные успешные реформы открыли широкие возможности для дальнейшего развития частного сектора в сельскохозяйственной сфеpe.

Оценивая роль аграрного сектора в экономике страны, становится ясно, насколько необходимы реформы в этом секторе. Аграрный сектор является в первую очередь основным источником сырья для промышленных предприятий, обеспечивает значительную часть потребительских товаров страны, решает проблему занятости, увеличивает приток иностранной валюты в страну и, наконец, играет роль гаранта продовольственной и экономической безопасности.

Полный период аграрных реформ в Азербайджане включает экономический рост на основе ВВП, динамику экономического роста за последнее десятилетие, долю аграрного сектора в этой динамике, динамику аграрного сектора в последнее десятилетие, а также долю аграрного сектора в инновационном развитии экономики.

Современное экономическое и социальное развитие основано на активизации инновационной деятельности и широком использовании инновационных технологий, продуктов и услуг. В настоящее время 70\% роста мирового ВВП приходится на новые знания, направленные на создание и управление инновационными технологиями.

Предварительный анализ показал, что инновации в аграрном секторе создают следующие преимущества: экономические, социальные, экологические, технические, технологические, торговые, бюджетные и т.д. Эти преимущества, в свою очередь, формируют рост интенсивного развития в аграрном секторе. Темпы роста (относительные темпы роста) аграрного сектора определяются по следующей формуле: [11]

$$
\Delta Y_{t}=\frac{Y_{t}-Y_{t-1}}{Y_{t-1}} * 100 \%
$$

Здесь

$Y_{t}$ - национальный доход в аграрном секторе в $\mathrm{t}$ году;

$Y_{t-1}$ - прошлогодний национальный доход в аграрном секторе по сравнению с годом t;

$\Delta Y_{t}$ - Темпы развития аграрного сектора.

Темпы экономического развития аграрного сектора складываются из двух составляющих: экстенсивного и интенсивного типа развития.

$$
\Delta Y_{t}=\left(\Delta Y_{t}\right)_{i n}+\left(\Delta Y_{t}\right)_{e x}
$$

Применение новых технологий, результаты научных и инновационных исследований оказывают влияние на темпы интенсивного развития аграрного сектора $[8,10]$.

Идеи Шумпетера, основателя теории инноваций, широко используются при формировании и применении инновационных процессов в сельском хозяйстве. По мнению Шумпетера, инновационные изменения в производстве и продаже товаров (услуг) являются ключевым показателем развития [8].

Инновации означают новые научно-технические идеи, новые продукты, новые технологии, новые производственные процессы, открытие новых рынков. Инновации могут нарушить баланс, который приведет к изменениям в системе цен, затрат и доходов. В результате оборот нерентабельных продуктов прекращается и практически полностью исключается, и стимулируется инновационный механизм, который постоянно поддерживает рыночный процесс. «Инновационная экономика (экономика знаний, интеллектуальная экономика) - это тип экономики, основанный на потоке инноваций, постоянном совершенствовании технологий, производстве и экспорте высокотехнологичных 
продуктов и технологий с высокой добавленной стоимостью. Главная особенность концепции Шумпетера заключается в том, что она ориентирована на «человеческий фактор» [8].

Применение новых технологий и инноваций в аграрном секторе оказывает непосредственное влияние на темпы интенсивного развития и увеличивает его значение.

Одним из основных компонентов научной стратегии по обеспечению инновационного агроэкономического роста в Азербайджане является внедрение результатов новых инновационных научных исследований, направленных на повышение качества сельскохозяйственных культур наряду с увеличением объема и продуктивности за счет применения новых эффективных сельскохозяйственных технологий. В результате этих исследований было выявлено, что увеличение доли генетически чистых (или генетически очищенных) сортов в общем объеме производства, оказывает существенное влияние на производство качественных продуктов и продовольственную безопасность. Следует отметить, что в последнее время одним из основных направлений аграрной политики является экологизация сельского хозяйства. Это связано с растущим спросом на экологически чистые продукты питания, выращенные без применения минеральных удобрений и пестицидов. В связи с этим следует провести исследования для формирования системы, обеспечивающей производство высококачественных, экологически чистых продуктов из сельскохозяйственных культур и следует рассмотреть применение информационных технологий и современных инновационных методов отбора проб для этих исследований.

Участие системы в разработке научных основ аграрной экономики посредством анализа полученных данных, определения будущей стратегии в аграрной сфере и обеспечения информационной поддержки работы механизмов принятия решений играет важную роль.

Правильный выбор пахотных земель, рациональное использование поливной воды, влияние нехватки воды, регулирование органических и минеральных удобрений, вносимых в почву в соответствии со стандартами, определение качества почвы и т.д. играют важную роль в развитии аграрного сектора.

По данным экономических и социальных центров, изучающих опыт сельскохозяйственного сектора в мире, 1 га плодородных земель должен обеспечивать семью, состоящую из 4-5 человек. При таких показателях 1 миллион гектаров земли может обеспечить продовольствием
4-5 миллионов человек. Это означает, что все земельные ресурсы должны быть использованы для обеспечения полной продовольственной безопасности. Прежде всего, учитывая, что в стране приблизительно 0,195 га пахотных земель и 0,53 га сельскохозяйственных угодий на душу населения, для большей эффективности пахотных земель их использование для других целей должно быть запрещено. Наряду с этим необходимо предотвратить опустынивание, эрозию и засоление существующих земель.

В то же время, непригодные земли должны быть восстановлены. Но следует также учитывать, что восстановление этих территорий займет много времени и больших денег.

Таким образом, подводя итоги вышеизложенному следует отметить, что для более успешной инновационной реформы в сельскохозяйственном секторе целесообразно соблюдение ряда нижеследующих мер:

Отдать предпочтение эффективным инновационным методам, используемым при выращивании основных продовольственных культур, включенных в потребительскую корзину.

Обобщить теоретические и экономические концепции для восстановления плодородия почв, которое играет ключевую роль в повышении урожайности сельскохозяйственных культур

Использовать различные базы данных для составления экономических счетов, информации о стоимости и количестве рабочей силы в аграрном секторе, структуре сельского населения их миграции

Изучить стоимости рабочей силы, структуры предпринимательства, экономических и других характеристик, экономической активности населения и других показателей в зависимости от социально-экономического положения домохозяйств при проведении наблюдений за занятостью в сельском хозяйстве;

Использовать более эффективные модели для оценки зависимости факторов окружающей среды от роста и продуктивности сельскохозяйственной продукции,

Повысить внимание к определению устойчивого развития в сельских районах путем сбора необходимой статистики (социальной, демографической, экономической и т.д.)

Применить совершенные противоэрозионные меры на уровне современных требований для эффективного землепользования; 
Обобщить мировой опыт исследований в области сельского хозяйства с целью повышения эффективности исследований сельскохозяйственных культур, провести конкретные анализы с учетом особенностей развития страны в области сельского хозяйства;
Создать новую инновационную модель аграрного экономического развития в Азербайджане с учетом специфики аграрного сектора и составляющей социально-экономического развития, обобщить результаты, полученные исследователями зарубежных стран.

\section{ЛИТЕРАТУРА}

1. «Государственная программа социально-экономического развития регионов Азербайджанской Республики (2004-2008 гг.) Баку, Nurlan, 2004

2. «Государственная программа социально-экономического развития регионов Азербайджанской Республики (2009-2013 гг.) Баку, Nurlan, 2009

3. Государственная программа по надежному обеспечению продовольствием населения в Азербайджанской Республике на 2008-2015 годы, URL: http:// www.e-qanun.az/framework/15320 (дата обращения 21.03.2021)

4. Гасымлы В. Экономическая модернизация. Центр стратегических исследований при Президенте Азербайджанской Республики. — Баку, 2014. — 311 с

5. Концепции развития «Азербайджан 2020: взгляд в будущее». URL: https://president.az/files/future_ru.pdf (дата обращения 19.03.2021)

6. Салахов С. Инновационное развитие сельскохозяйственного сектора: реалии и перспективы: сборник научных трудов Аz.ETTкі и Tі, Восток-Запад.- - Баку, 2012. - 242c

7. Эминов Н.О. Направления развития современного предпринимательства в основе инновационно направленного экономического развития // Вестник НАНА. 一 2012. 一 № 2. - C. 27.

8. Шумпетер Й. Теория экономического развития. Капитализм, социализм и демократия. М, Эксмо, 2007-864 с.

9. Audsley E., Dumont S. and Boyce D.S. An economic comparison of methods cultivating and planting cereals, sugar beet and potatoes and their interaction with harvesting, timeliness an available labour by linear programming-Journal of Agricultural Engineering Research 23, 283-300., 1978

10. Dalton G.E. (ed) Study of Agricultural systems-London: Applied Science Publishers. 1975

11. Dent J.B. and Anderson J.R. (ed) Systems Analysis in Agricultural Management-Sydney: Wiley.1971

12. Lundvall, Bengt-Åke. Product Innovation and User-Producer Interaction. Aalborg, Denmark: Aalborg University Press. 1985

13. Martin B. Research Foresight and the exploitation of science base. HSMO, London, 1993.

14. Spedding C.R.W. An introduction to Agricultural Systems-London: Applied Science Publishers. 1979

15. https://www.stat.gov.az/ (дата обращения 15.03.2021)

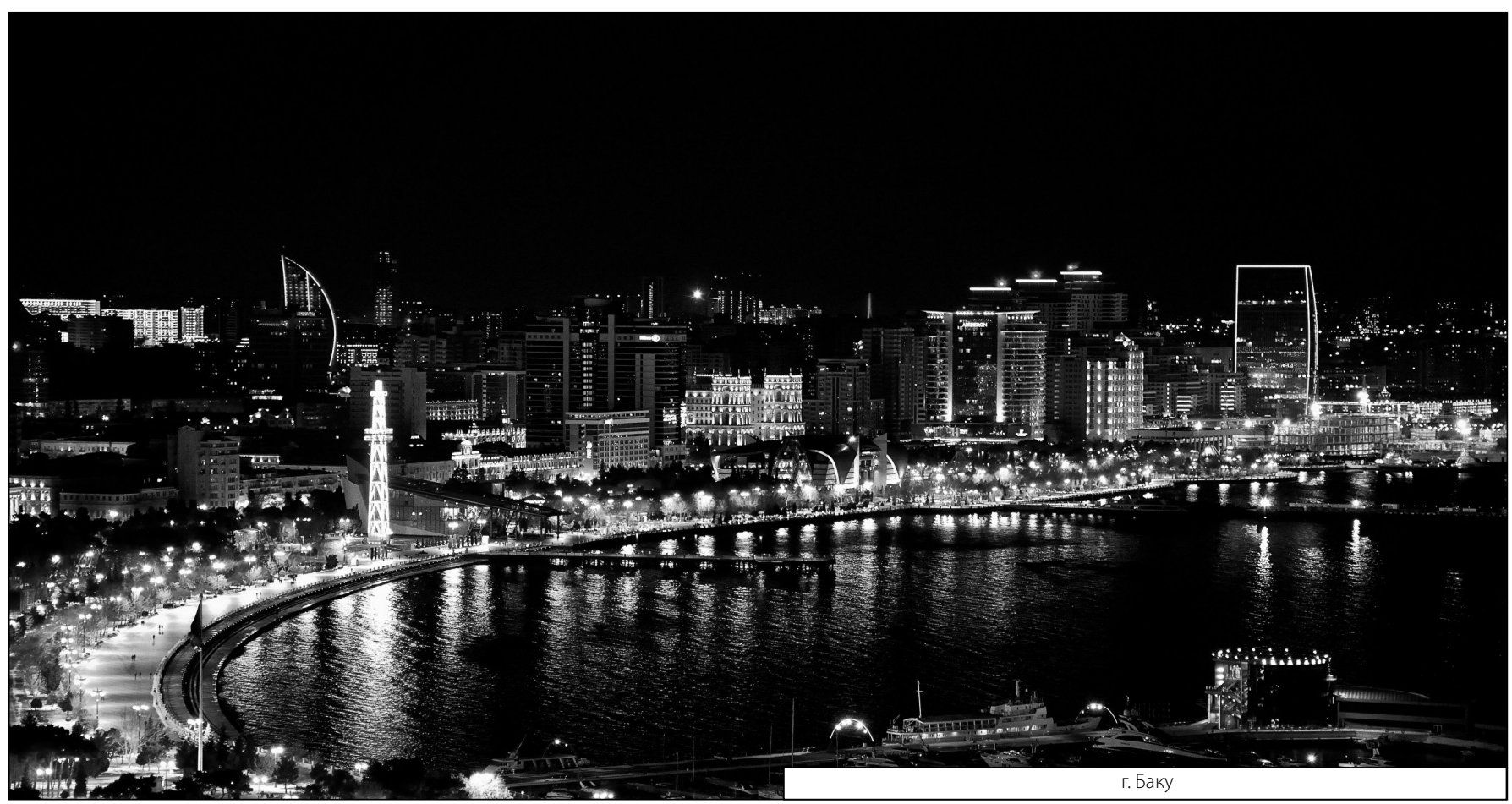

